\title{
Late Holocene Peatland Evolution in Terelj and Tuul Rivers Drainage Basins in the Khentii Mountain Range of Northeastern Mongolia
}

\author{
Alexander Orkhonselenge ${ }^{1, *}$, Munkhjargal Uuganzaya ${ }^{1}$, Tuyagerel Davaagatan ${ }^{1,2}$ and Ganbaatar Enkhbayar $^{3}$ \\ 1 Laboratory of Geochemistry and Geomorphology, School of Arts and Sciences, National University of \\ Mongolia, Ulaanbaatar 14201, Mongolia; m.uuganzayaaa@gmail.com (M.U.); dtuyagerel@gmail.com (T.D.) \\ 2 Division of Physical Geography, Institute of Geography and Geoecology, Mongolian Academy of Sciences, \\ Ulaanbaatar 15170, Mongolia \\ 3 School of Industrial Technology, University of Science and Technology, Ulaanbaatar 14191, Mongolia; \\ bayaraa1240@gmail.com \\ * Correspondence: rkhnslng@num.edu.mn; Tel.: +976-77307730-2453
}

Citation: Orkhonselenge, A.; Uuganzaya, M.; Davaagatan, T.; Enkhbayar, G. Late Holocene Peatland Evolution in Terelj and Tuul Rivers Drainage Basins in the Khentii Mountain Range of Northeastern Mongolia. Water 2021, 13, 562. https://doi.org/10.3390/w13040562

Academic Editor: Michał Słowiński

Received: 5 January 2021

Accepted: 19 February 2021

Published: 23 February 2021

Publisher's Note: MDPI stays neutral with regard to jurisdictional claims in published maps and institutional affiliations.

Copyright: (C) 2021 by the authors Licensee MDPI, Basel, Switzerland. This article is an open access article distributed under the terms and conditions of the Creative Commons Attribution (CC BY) license (https:/ / creativecommons.org/licenses/by/ $4.0 /)$.

\begin{abstract}
This study reviews the late Holocene peatlands in Terelj River and Tuul River drainage basins in the Khentii (Khentii has been misspelled as Khentey (or Hentey) and Khentei (or Hentei) in many publications. The Khentii is the right English translation from Mongolian Хэнтий) Mountain Range of northeastern Mongolia. The peatlands were examined through their physical and chemical properties, diatom assemblages, and radiocarbon dating. In the Terelj River basin, the high contents of organic matter and biogenic silica and the dominant benthic diatom assemblages such as Eunotia praerupta, Pinnularia borealis, and Navicula mutica in the peat deposits indicate the warm and humid climates in the late Holocene. The high accretion rate of $0.97 \mathrm{~mm} / \mathrm{yr}$ in the peatland records the intensive erosion in the surrounding landscape and deposition in the peatland due to increased precipitation and runoff in the humid climate since $0.5 \mathrm{cal}$. ka BP. In the Tuul River basin, the high content of mineral fractions and diatom assemblages dominated by benthic species Cymbella proxima, Encyonema silesiacum, and planktonic species Cyclotella ocellata in the peat deposits show a transition from humid to arid climates at $0.9 \mathrm{cal}$. $\mathrm{ka}$ BP. The accretion rate of $0.56 \mathrm{~mm} / \mathrm{yr}$ in the peatland on the paleo-floodplain indicates strengthened erosion in the peatland over the past 1000 years. This study in the southern Khentii Mountain Range provides new descriptive insights to extend the underestimated Mongolia's peat studies, and it would be a useful proof-of-concept study for future detailed paleo-environmental analyses.
\end{abstract}

Keywords: peatland; wetland; water resources; climate change; Tuul; Terelj; Khentii; Mongolia

\section{Introduction}

Peatland represents an essential archive of water resources in Mongolia. Understanding the spatial and temporal patterns of peatland distribution in northern Mongolia is particularly important in the reconstruction of paleoclimate in Eurasia.

Mongolia, located between the Siberian taiga forest in the north and the Govi (Govi has been often spelled as Gobi in the international literature. The Govi is the correct English translation from Mongolian Говь) (or Gobi) desert of Central Asia in the south, has a typical continental climate developed under the East Asian winter monsoon and the westerlies. Data on past climate changes, especially during the Holocene, allow us to understand how various landscapes in Mongolia may respond to future climatic scenarios. The general picture of the Holocene climate history in Mongolia is still open to debate, although there is consensus on some climatic changes. Numerous studies on paleoclimate changes in Mongolia have been conducted, and these were primarily based on lake sediments (e.g., [1-4]).

The distribution of peatlands in Mongolia, covering an area of $27,200 \mathrm{~km}^{2}$, shows that Mongolia has a high diversity and expanse of peatlands [5,6]. For instance, extensive 
peat formation occurs in permafrost zones (e.g., in the Khan Khukhii Mountain Range, the depression of Lake Uvs, Tes River valley), shallow lakes, oxbow lakes, backwaters, and springs $[6,7]$. The permafrost only thaws superficially and causes water stagnation and peat formation [7]. A similar phenomenon was found on the subalpine and alpine plateaus of the Khangai Mountain Range [8]. Moreover, the mire in the Khuder River basin in the Khentii Mountain Range is one of the most extensive peatlands in Mongolia [9], and it is included in a peatland system situated at the montane belt at an elevation of 1200-1600 m a.s.l. [10].

In the $1960 \mathrm{~s} / 70 \mathrm{~s}, 1.74 \%$ of the total area of Mongolia was covered by peatlands [6]; however, comparative spatial analysis in 2015-2016 showing a significant decrease in the peatland area of Mongolia $~ 1 \%$ of the territory in the country [11]. According to the International Mire Conservation Group's Global Peat Land Database [12], Mongolia's peatlands contain 750 megatons of carbon and emit 45 megatons of $\mathrm{CO}_{2}$ per year. This puts Mongolia in the top ten of the world's peatland $\mathrm{CO}_{2}$ emitters [13]. There are only a few ecological studies based on these peat archives [14]. In 2003, the Institute of Botany of the Mongolian Academy of Sciences (MAS), Institute for Problems in Ecology and Evolution of the Russian Academy of Sciences (RAS), MonMap, and Wetlands International initiated integrated research on peatlands in Mongolia. Moreover, in 2007 and 2013, the joint Russian and Mongolian Complex Biological Expedition conducted peatland surveys in Mongolia. According to previous studies by Russian scientists (e.g., [15]), the dating of the onset of peat formation in Mongolia is unclear. Still, Fukumoto et al. [16] reconstructed the Holocene sphagnum bog in the Khuder peatland inferred from diatom and pollen assemblages.

Recent climate change significantly influences the Mongolian peatlands. For instance, in addition to the present climate change, peatlands in the Orkhon River valley are damaged by overgrazing, desertification, mining, road construction, and human-caused steppe fires [17]. During dry periods, which may continue for years, the moisture preserved in the peatlands is a source of life and a barrier to desertification [7]. Wetlands International developed a strategic plan for peatland conservation, restoration, and sustainable management in Mongolia because of Mongolian peatlands' current rapid loss, preserving permafrost and other water sources in highlands and large river valleys $[17,18]$.

This study aims to reveal peatland features in northeastern Mongolia and presents physical and chemical characteristics and diatom assemblages of peat deposits in Terelj River and Tuul River drainage basins in the southern Khentii Mountain Range. It compares the records with those from the Khuder peatland in the northern Khentii Mountain Range [16].

\section{Materials and Methods}

\subsection{Physiographic Condition}

Khentii Mountain Range (Figure 1) extends from the Russian border in the northeast of Mongolia (Figure 1A) to Mt. Bogd (Figures 1B and 2E) in the southwest, with an average elevation of $1600 \mathrm{~m}$ a.s.l, ranging from the highest point, Mt. Asralt Khairkhan (2800 $\mathrm{m}$ a.s.l.) to the lowest point, estuary of Yeruu River (600 $\mathrm{m}$ a.s.l.). This range is predominantly composed of early Paleozoic and Mesozoic granites and consists of domeshaped tops, peaks with steep gorges and cliffs, and valleys with gentle slopes formed by the Pleistocene glaciations [19-21]. 


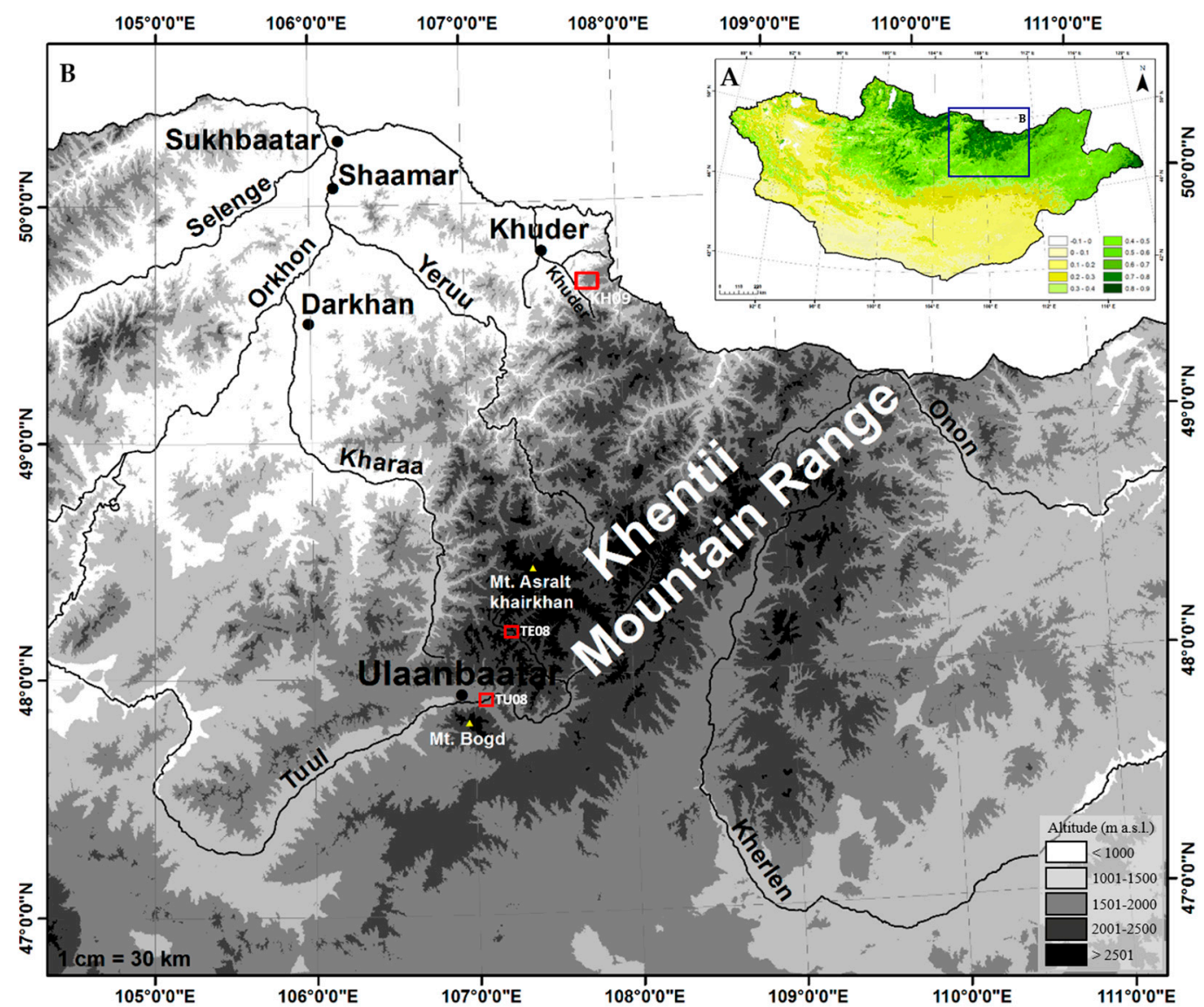

Figure 1. (A) The normalized difference vegetation index (NDVI) of Mongolia in 2015. Modified from Orkhonselenge et al. [22]. The box indicates the location of Khentii Mountain Range. (B) Physiography of Khentii Mountain Range with locations of coring sites in Terelj River (TE08), Tuul River (TU08) and Khuder River (KH09) drainage basins. Modified from Orkhonselenge and Uuganzaya [23]. Results from the core KH09 were published in Fukumoto et al. [16].

The climate of the Khentii Mountain Range is characterized by large annual temperature variations [24]. The average air temperature ranges from $-0.9^{\circ} \mathrm{C} / \mathrm{yr}$ to $1.5^{\circ} \mathrm{C} / \mathrm{yr}$ [25] or $-2.0^{\circ} \mathrm{C} / \mathrm{yr}$ to $1.1^{\circ} \mathrm{C} / \mathrm{yr}$ [26]. The average air temperature is $-35.4^{\circ} \mathrm{C}$ to $-43.3^{\circ} \mathrm{C}$ in January and $18.8^{\circ} \mathrm{C}$ in July, and the average precipitation is $350-400 \mathrm{~mm} / \mathrm{yr}[22,26]$.

The Khentii Mountain Range feeds large rivers (e.g., Onon River in the northeast, Kherlen River in the southeast, Tuul River in the southwest, and Kharaa, Yeruu and Khuder Rivers in the northwest in Figure 1B), that are major headwaters of large rivers (e.g., Amar, Shilka Rivers) and lakes (e.g., Lakes Baikal (Baigali meaning nature has been misspelled as Baikal based on the Russian pronunciation. The Baigali is the right English translation from Mongolian Байгаль), Tari (Tari has been misspelled as Torey by the Russians. The Tari is the right English translation from Mongolian Тарь)) in the North Arctic Ocean and Pacific Ocean drainage basins. These large rivers play a valuable role in surface water resources in northern and eastern Mongolia and effectively record the regional moisture balance. Terelj River is one of Tuul River's headwaters, whereas the Tuul River is a major tributary of Orkhon River and the Selenge (Selenge has been often incorrectly written as Selenga internationally based on the Russian pronunciation. The Selenge is the correct English translation from Mongolian Сэлэнгэ) River (Figure 1B). 


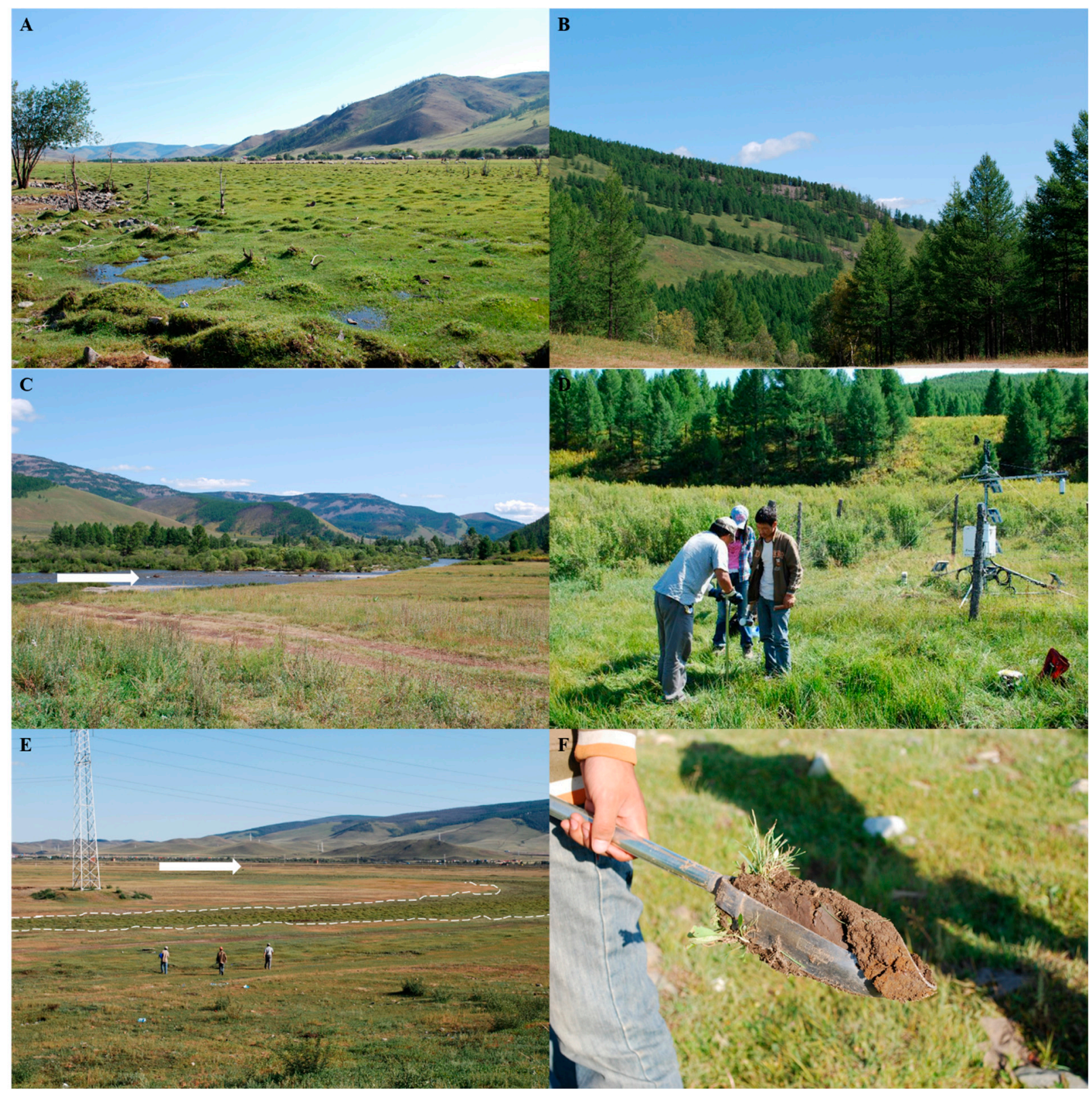

Figure 2. Sampling sites in Khentii Mountain Range. (A) The peatland with mounds of seasonal permafrost viewing toward the southwest. (B) Mt. Davaat viewing toward the west. (C) Terelj River viewing toward the southwest from (D), and the arrow indicates the flow direction of Terelj River. (D) The sampling of the core TE08 (Figure 1B). (E) The peatland with mounds of seasonal permafrost (dashed curve) viewing toward the north, and the arrow indicates the flow direction of Tuul River in the northeast of Mt. Bogd (Figure 1B). (F) Surface sediments at the sampling site for the core TU08 (Figure 1B). Photos by A. Orkhonselenge on 20 August 2008.

The Khentii Mountain Range becomes the southernmost tip of the Siberian permafrost region (Figure 2A), merging into central Mongolia's prairie. It is known for its high diversity of vegetation types [27], from the Siberian taiga Larix and Betula forests (Figure 2B-D) to Mongolian steppe vegetation. The average normalized difference vegetation index (NDVI) of the Khentii Mountain Range varies from 0.7 to 0.9 (Figure 1A).

\subsection{Fieldwork}

The fieldwork was undertaken in August 2008, and numerous core samples were obtained from Terelj River and Tuul River drainage basins in Khentii Mountain Range 
(Figure 1). This study presents two short cores obtained from peatlands in Terelj River and Tuul River drainage basins (Figure 1B).

The first sampling core TE08 (Figure 1B) was taken from the peatland at an elevation of $1635 \mathrm{~m}$ a.s.1. $\left(48^{\circ} 08^{\prime} 2.59^{\prime \prime} \mathrm{N}, 107^{\circ} 18^{\prime} 22.04^{\prime \prime} \mathrm{E}\right)$ in Terelj River basin (Figure 2C,D). In the core TE08, the upper $0.7 \mathrm{~m}$ consists mostly of a dark mud organic humus layer, while the lower $0.3 \mathrm{~m}$ consists of grey sands. The second sampling core TU08 (Figure 1B) was obtained from the peatland at an elevation of $1313 \mathrm{~m}$ a.s.l. $\left(47^{\circ} 54^{\prime} 40.37^{\prime \prime} \mathrm{N}, 107^{\circ} 02^{\prime} 39.05^{\prime \prime} \mathrm{E}\right)$ on the paleo-floodplain of Tuul River (Figure 2E,F). The core TU08 consists of an organic humus layer at the surface and inorganic grey-brown coarse mud with silts and sands at the bottom.

\subsection{Biogenic Silica, Grain Size, and Diatom Analyses}

Biogenic silica (BioSi) analysis was performed according to the spectrophotometric method proposed by Mortlock and Froelich [28] at hydrogeomorphological laboratory, Kanazawa University in Japan. With the BioSi analysis, physical and chemical parameters, including plant organic matter, carbonates, $\mathrm{BioSi}$, and mineral fraction, were measured. Grain sizes of the peat deposits were analyzed for the bulk sediment and mineral fraction with SALD-2200 laser diffraction particle size analyzer. A calculation of the distribution of grain sizes was done on the Wing-1 program.

Diatom assemblages were examined using Watanabe's taxonomy [29] at Terrestrial Paleoenvironmental Laboratory, Kyushu University in Japan. For the diatom analysis, the samples were prepared by smear glass slides for each $10 \mathrm{~cm}$ depth and dried at $60^{\circ} \mathrm{C}$ on cover glasses for the bulk sediment, which was subsequently mounted on micro slides with Naphrax for scanning electron microscopy. An Olympus BX50 light microscope with bright field and differential interference contrast (DIC) optics capable of NA $=1.40$ and $100 \times$ was used. On each slide, the diatom genus was identified and counted at $~ 500$ diatom valves without any fragments under the light microscopy.

\subsection{Radiocarbon Dating}

Radiocarbon $\left({ }^{14} \mathrm{C}\right)$ dating was performed by accelerator mass spectrometry (AMS) at Paleo Labo Co., Ltd. in Japan. For the ${ }^{14} \mathrm{C}$ dating, $1 \mathrm{~cm}$ thick bulk samples were taken at each $50 \mathrm{~cm}$ depth in the cores TE08 and TU08. Choosing the same depth for the cores aimed to set up preliminary background about the sites for further detailed investigations.

The ${ }^{14} \mathrm{C}$ ages were calibrated using the calibration program Oxcal version $4.0[30,31]$ with the calibration date set of IntCal04 [32]. Calibrated ages (cal.) were chosen using the midpoint of the two sigma ( $2 \sigma$ ) standard deviation range (Table 1$)$.

Table 1. Radiocarbon ages without $\delta^{13} \mathrm{C}$ correction and calibrated ages for each $50 \mathrm{~cm}$ depth in the cores TE08 and TU08.

\begin{tabular}{|c|c|c|c|c|c|c|}
\hline \multirow{2}{*}{ Sample No. } & \multirow{2}{*}{ Lab. No. } & \multirow{2}{*}{$\delta^{13} \mathrm{C}(\%)$} & \multirow{2}{*}{$\begin{array}{c}{ }^{14} \mathrm{C} \text { Age } \\
(\mathrm{yr} \mathrm{BP} \pm 1 \sigma)\end{array}$} & \multirow{2}{*}{$\begin{array}{l}\text { Age for Calibration } \\
\quad(\mathrm{yr} \mathrm{BP} \pm 1 \sigma)\end{array}$} & \multicolumn{2}{|c|}{ Calibrated ${ }^{14} \mathrm{C}$ Age } \\
\hline & & & & & $1 \sigma$ & $2 \sigma$ \\
\hline TE08-1 & PLD-11868 & $-29.05 \pm 0.16$ & $380 \pm 25$ & $380 \pm 23$ & $\begin{array}{c}1452-1496 \mathrm{AD} \\
(51.3 \%) \\
1602-1616 \mathrm{AD} \\
(14.5 \%) \\
1508-1511 \mathrm{AD} \\
(2.3 \%)\end{array}$ & $\begin{array}{c}1446-1523 \mathrm{AD} \\
(69.0 \%) \\
1573-1627 \mathrm{AD} \\
(26.4 \%)\end{array}$ \\
\hline TU08-1 & PLD-12736 & $-28.40 \pm 0.16$ & $910 \pm 20$ & $909 \pm 19$ & $\begin{array}{c}1048-1088 \mathrm{AD} \\
(41.8 \%) \\
1122-1139 \mathrm{AD} \\
(15.0 \%) \\
1150-1162 \mathrm{AD} \\
(11.4 \%)\end{array}$ & $\begin{array}{c}1038-1180 \mathrm{AD} \\
\quad(95.4 \%)\end{array}$ \\
\hline
\end{tabular}




\section{Results}

\subsection{Physical and Chemical Characteristics}

In the Terelj River basin, the grain size of bulk sediments in the core TE08 shows medium to very fine silts (Figure 3A). It ranges at 5.3-6.4 $\varphi$ in 10-70 cm depth and 7.0-7.8 $\varphi$ in $80-100 \mathrm{~cm}$ depth (Figure $3 \mathrm{~A}$ ). The mineral fractions vary from fine to medium sands (Figure 3B). The grain size of mineral fractions is $2.0-2.5 \varphi$ in 10-70 cm depth and 1.6-1.9 $\varphi$ in $80-100 \mathrm{~cm}$ depth (Figure 3B).
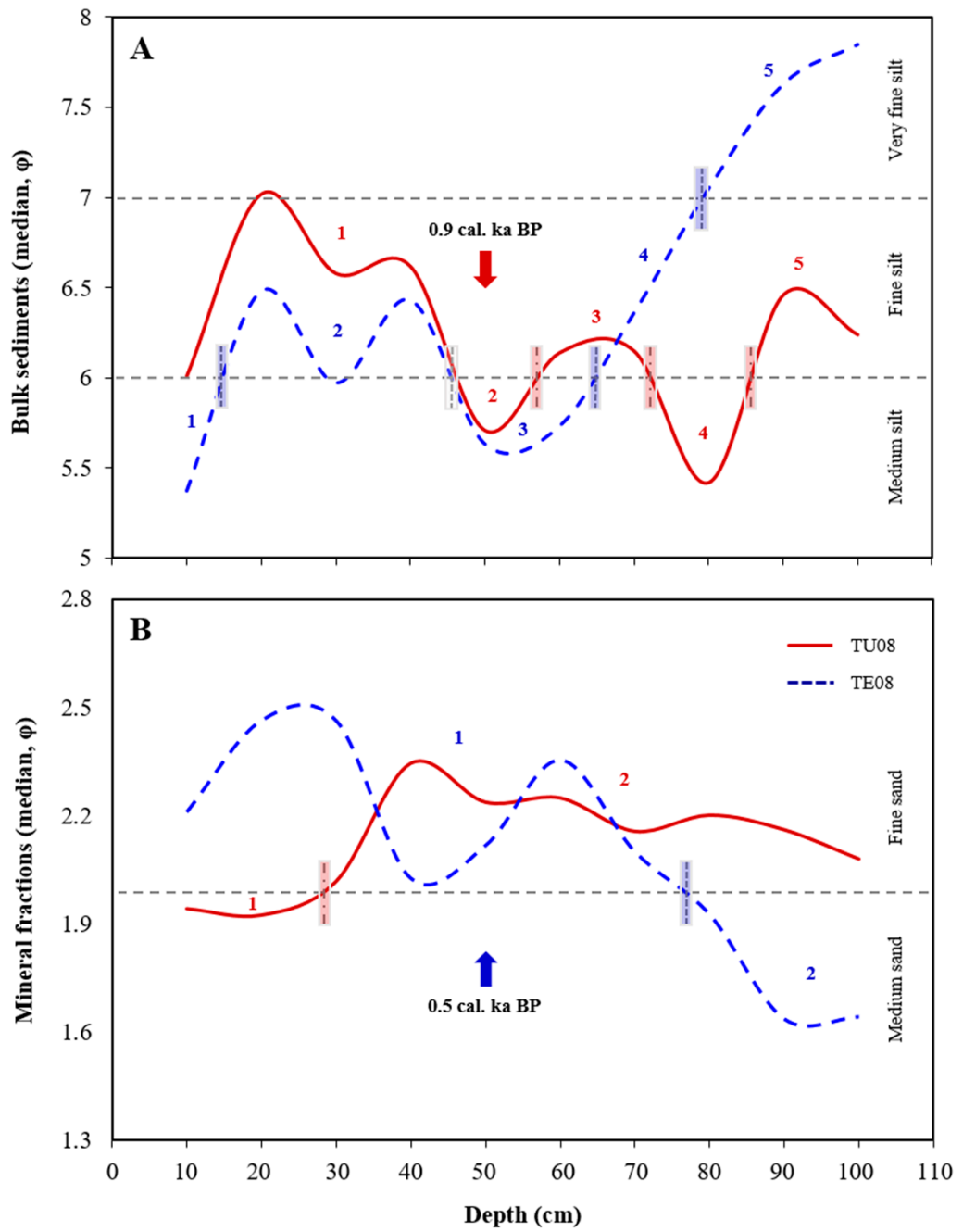

Figure 3. Grain size distributions of (A) bulk sediments and (B) mineral fractions in the peat deposits for the cores TE08 and TU08 with the ages. Numbers indicate periods of grain size changes implying sedimentation events, and gray-scale bars indicate the events' borderline.

The core TE0 8 consists of $46.6 \%$ organic matter, $20.2 \%$ carbonates, $7.4 \% \mathrm{BioSi}$, and $25.8 \%$ mineral fraction (Figure $4 \mathrm{~A}$ ). The organic matter, carbonates, and BioSi increase above $40 \mathrm{~cm}$ depth and at 60-80 $\mathrm{cm}$ depth, but decrease between 40 and $60 \mathrm{~cm}$ depth and below $80 \mathrm{~cm}$ depth (Figure $4 \mathrm{~A}$ ). The organic matter reaches $\sim 80 \%$ above $20 \mathrm{~cm}$ depth. 

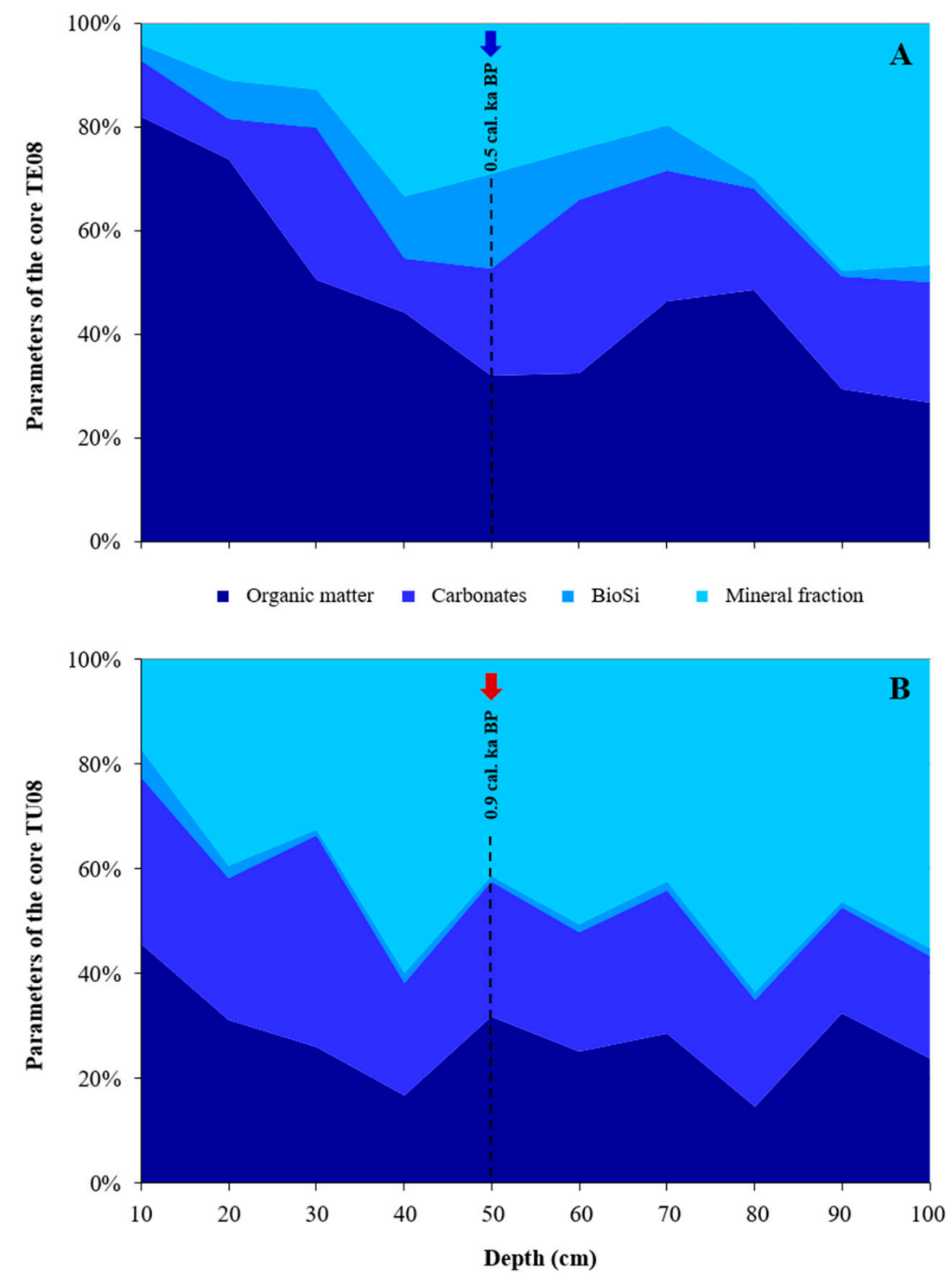

Figure 4. Physical and chemical parameters with the ages for the cores (A) TE08 and (B) TU08: organic matter, carbonate, BioSi, and mineral fraction.

In the Tuul River basin, the grain size of bulk sediments in the core TU08 shows fine to medium silts (Figure 3A). The bulk sediments are at 5.3-7.1 $\varphi$ in the core TU08 ranging from more than $6.5 \varphi$ above $40 \mathrm{~cm}$ depth and below $90 \mathrm{~cm}$ depth to less than $6.5 \varphi$ in $40-90 \mathrm{~cm}$ depth (Figure 3A). The grain size of mineral fractions in the core TU08 indicates medium to fine sands (Figure 3B). The mineral fractions are less than $2.0 \varphi$ above $30 \mathrm{~cm}$ depth and more than $2.0 \varphi$ below $30 \mathrm{~cm}$ depth.

The core TU08 consists of $27.6 \%$ organic matter, $25.7 \%$ carbonates, $1.9 \% \mathrm{BioSi}$, and $44.8 \%$ mineral fractions (Figure 4B). The organic matter, carbonates, and BioSi increase above $30 \mathrm{~cm}$ depth, 50-70 cm depth, and below $90 \mathrm{~cm}$ depth, but decrease in 30-50 cm and $70-90 \mathrm{~cm}$ depths (Figure 4B). The organic matter reaches $\sim 40 \%$ above $20 \mathrm{~cm}$ depth.

\subsection{Diatom Assemblages}

The dominant diatom species among the diatom valves in $50 \mathrm{~cm}$ depth are shown in Figures 5 and 6. 


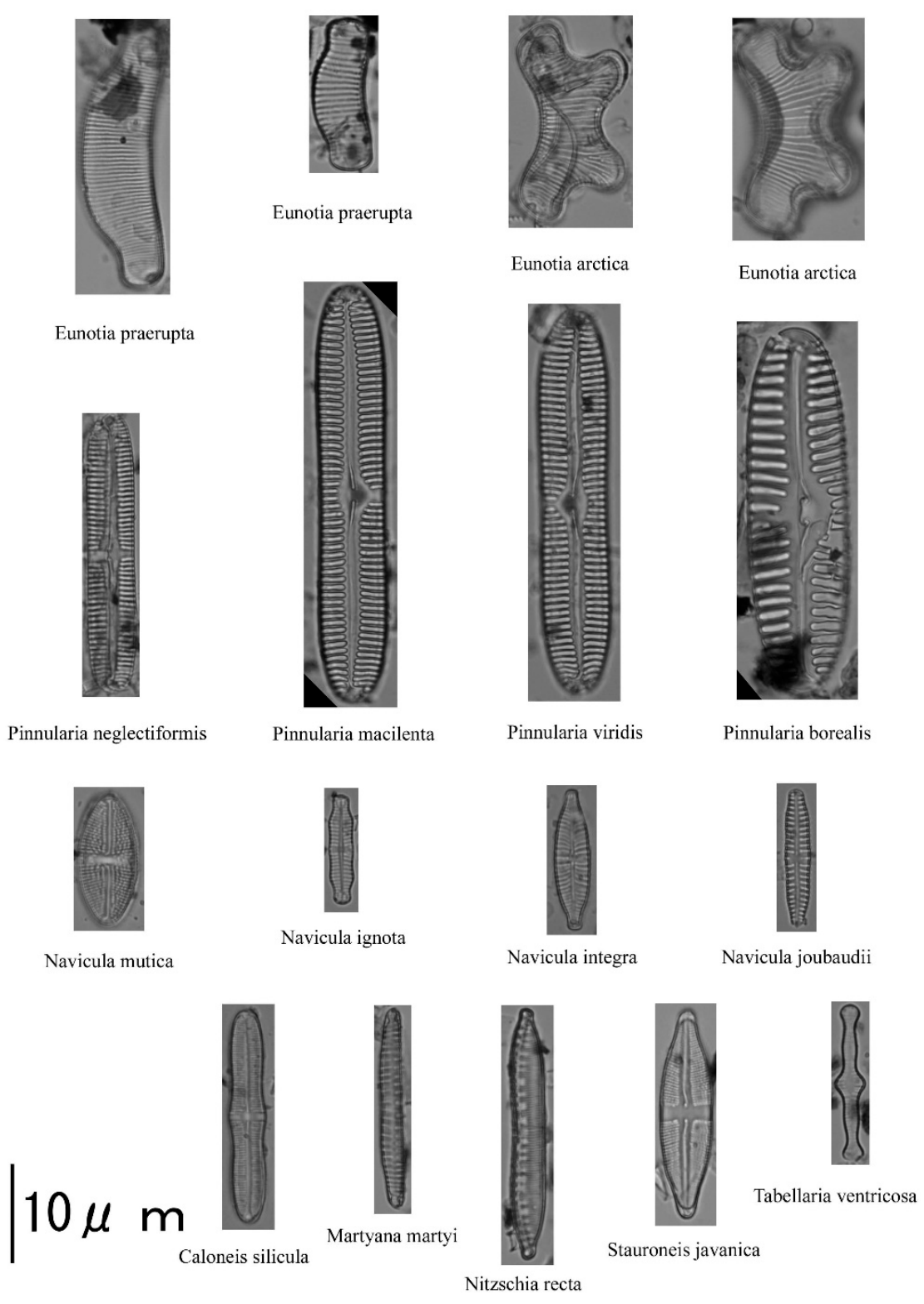

Figure 5. The dominant species of the diatom assemblages in $50 \mathrm{~cm}$ depth for the core TE08 in the Terelj River basin.

The peat deposits in the Terelj River basin contain abundant benthic diatom assemblages. The dominant species in $50 \mathrm{~cm}$ depth in the core TE08 (Figure 5) are Eunotia praerupta, Eunotia arctica, Pinnularia neglectiformis, Pinnularia macilenta, Pinnularia viridis, Pinnularia borealis, Pinnularia subcapitata, Navicula mutica, Navicula ignota, Navicula integra, Navicula joubaudii, Caloneis silicula, Stauroneis javanica, Tabellaria ventricosa, Martyana martyi, Nitzschia recta, Gomphonema hebridense, Gomphonema brebissonii, Encyonema silesiacum, Cymbella cuspidate, Hannaea arcus, and Neidium iridis.

The peat deposits in the Tuul River basin also contain abundant benthic diatom assemblages with a planktonic diatom. Among the abundant diatom assemblages in $50 \mathrm{~cm}$ depth in the core TU08, the dominant species (Figure 6) are Cymbella proxima, Cymbella sumatrensis, Cymbella cistula, Cymbella novazeclandiana, Cyclotella ocellata, Encyonema silesiacum, Fragilaria capucina, Achnanthes lanceolata, Reimeria sinnuata, Punctastriata linearis, Gomphonema heterominuta, Gomphonema ovaliceum, Gomphonema angustivalva, Gomphonema brebissonii, Stauroneis lapponica, Amphora ovalis, Amphora copulate, Cocconeis placentula, and Synedra ulna. 


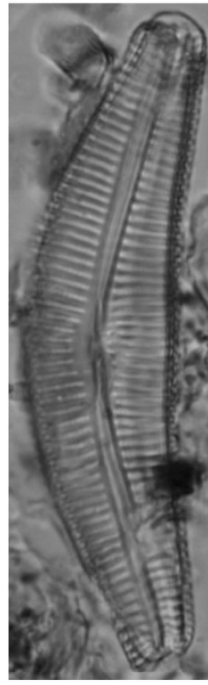

Cymbella proxima

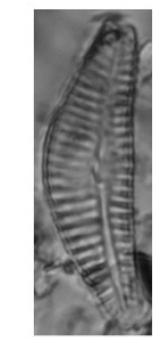

Cymbella sumatrensis
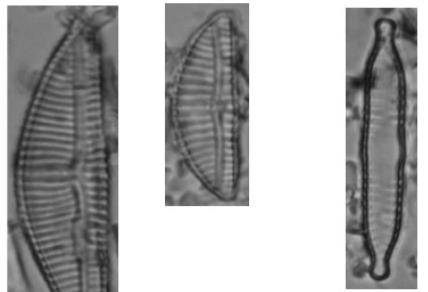

Fragilaria capucina

Encyonema silesiacum

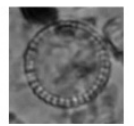

Cyclotella ocellata

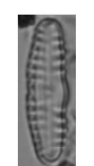

Reimeria sinuata

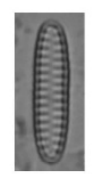

Punctastriata linearis

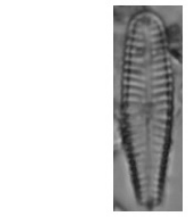

Gomphonema heterominuta
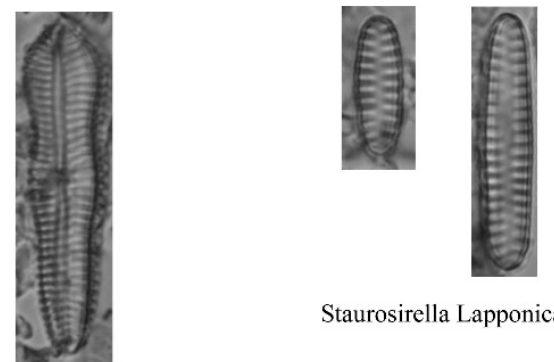

Staurosirella Lapponica

Gomphonema brebissonii

\section{$10 \mu \mathrm{m}$}

Figure 6. The dominant species of the diatom assemblages in $50 \mathrm{~cm}$ depth for the core TU08 in the Tuul River basin.

\subsection{Radiocarbon Age and Accretion Rate}

The AMS estimates the peat deposit in $50 \mathrm{~cm}$ depth in the Terelj River basin at ca. 1485 years (Table 1), and the accretion rate is about $0.97 \mathrm{~mm} / \mathrm{yr}$. The peat deposit in $50 \mathrm{~cm}$ depth in the Tuul River basin is estimated at ca. 1109 years (Table 1), and the accretion rate is about $0.56 \mathrm{~mm} / \mathrm{yr}$. The accretion rates are for the upper $50 \mathrm{~cm}$ depth in each core.

\section{Discussion}

The physical and chemical characteristics (Figures 3 and 4) and the dominant diatom species (Figures 5 and 6) indicate late Holocene peatland evolution in the southern Khentii Mountain Range of northeastern Mongolia. They are comparative with Holocene peatland development in the northern Khentii Mountain Range.

\subsection{Sedimentary Feature in the Drainage Basins}

Grain size distributions of the bulk sediments and mineral fractions in the peatlands show grain size changes meaning numerous sedimentation events in the river drainage basins (Figure 3) with different sources. In the Terelj River basin, two short-term events occurred since $0.5 \mathrm{cal}$. ka BP, but three short-term events were found prior to $0.5 \mathrm{cal}$. ka BP (Figure 3A). Whereas, in the Tuul River basin, a long-term event since 0.9 cal. ka BP, but three to four short-term events occurred before 0.9 cal. ka BP (Figure 3A). The mineral fractions show an event in the Terelj River basin each since and prior to $0.5 \mathrm{cal}$. ka BP, 
however, two events in the Tuul River basin since 0.9 cal. ka BP and an event before 0.9 cal. ka BP (Figure 3B).

In the Terelj River basin, deposition of the medium silts (Events 1 and 3 in Figure 3A) and high accretion rate since $0.5 \mathrm{cal}$. ka BP may have occurred during the pulse sedimentations due to heavy rainfall and flooding. However, the depositions of the fine to very fine silts (Events 4 and 5 in Figure 3A) mean the prevalence of arid climates prior to $0.5 \mathrm{cal}$. ka $\mathrm{BP}$ that may have contributed to the aeolian sedimentations. The high contents of organic matter and biogenic silica in the core TE08 (Figure 4A) indicate the intensive erosion of the surrounding landscape and the accumulation of organic materials in the peatland in warm and humid climates and coincide with the high organic matter and biogenic silica contents in the peatland recorded in the core KH09 in the Khuder River basin (Figure 1B) since 2.8 cal. ka BP [16] and Lake Khar sediments in southeastern Siberia during the last 1000 years [33]. In the Tuul River basin, the single long-term accumulation of the fine silts (Event 1 in Figure 3A) and low accretion rate since $0.9 \mathrm{cal}$. ka BP may have related to aeolian inputs in the arid climate. Moreover, the short-term sedimentations of the fine silts (Events 3 and 5 in Figure 3A) prior to 0.9 cal. ka BP may have also happened during the aeolian processes, but the short-term depositions of the medium silts (Events 2 and 4 in Figure $3 \mathrm{~A}$ ) might have occurred during the increased precipitation in the humid climates contributed to the fluvial inputs. The high content of mineral fractions in the core TU08 (Figure 4B) indicates the erosion of the paleo-floodplain and in-situ deposition of alluvial sediments in the peatland.

In the southern Khentii Mountain Range, the higher accretion rate occurred at $0.97 \mathrm{~mm} / \mathrm{yr}$ in the Terelj River basin than $0.56 \mathrm{~mm} / \mathrm{yr}$ in the Tuul River basin during the late Holocene. The high sedimentation in the Terelj River basin during the past 500 years may have been induced by the humid climate at $0.5 \mathrm{cal}$. ka BP (Figure 7) and is closer to the accretion rate of $0.8 \mathrm{~mm} / \mathrm{yr}$ in Lake Khuvsgul basin in northern Mongolia at $0.89 \mathrm{cal}$. ka BP [34]. Whereas the arid condition in the Tuul River basin since 0.9 cal. ka BP may have contributed to the low sedimentation over the last 1000 years. The peatland on the paleo-floodplain in the Tuul River basin is prone to fluvial and aeolian erosion because of its location in the open valley (Figure 2E), while the peatland in the Terelj River basin is situated within the Siberian taiga Larix and Betula forests (Figure 2D). These physiographic conditions of the peatlands and their surrounding landscapes may have contributed to the different sedimentary history in both river drainage basins. In other words, the fluvial and aeolian erosion is intense in the Tuul River basin, while the deposition dominates in the peatland even though erosion of the surrounding landscape occurs in the Terelj River basin during the late Holocene. However, the linear interpolation of an age-to-depth model shows that the average accretion rate of ca. $0.4 \mathrm{~mm} / \mathrm{yr}$ for the Khuder peatland and organic clay layers in the core KH09 [16]. Overall, the accretion rate in the peatlands in the southern Khentii Mountain Range is higher than those in the peatland in the northern Khentii Mountain Range because the Khuder peatland has no larger inflow rivers in comparison with the peatlands in the Terelj and Tuul River drainage basins. 


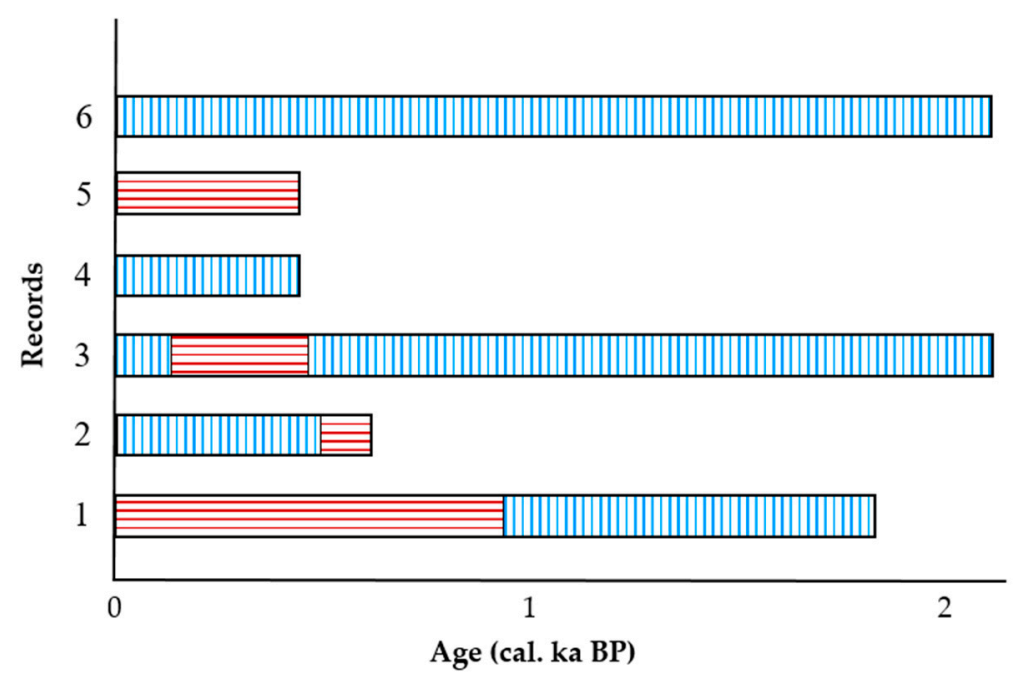

Figure 7. Late Holocene climate changes in northeastern Mongolia recorded from (1) Tuul River basin [this study], (2) Terelj River basin [this study], (3) Khuder River basin [16], (4) Lake Khagiin Khar basin [35], (5) Lake Gun basin [36], and (6) Shaamar area [37]. The vertical lines indicate the humid climate, but the horizontal lines indicate the arid climate.

\subsection{Diatom Assemblages}

The well-preserved diatom assemblages in the peatlands in the Khentii Mountain Range of northeastern Mongolia record the dominance of benthic diatoms in the Terelj River drainage basin at $0.5 \mathrm{cal}$. ka BP (Figure 5) and planktonic presence with benthic diatoms in the Tuul River basin at 0.9 cal. ka BP (Figure 6).

In the Terelj River basin (Figure 5), diatom species Eunotia praerupta, Pinnularia borealis, and Navicula ignota that thrive in shallow water (e.g., [38]), and genera Navicula and Nitzschia that occur in fine sediments in the Colorado River [39] were found. Moreover, Tabellaria, Eunotia, and Pinnularia in the core TE08 coincide with those abundances in the core KH09 in the Khuder peatland [16]. Eunotia species (e.g., E. pectinalis) have been characterized as being aerophilic [40]. Co-dominance of aerophilic species Pinnularia borealis and Navicula mutica marks a terrestrial environment at arid climate at $0.5 \mathrm{cal}$. ka BP (Figure 7). The genera Pinnularia and Navicula in the core TE08 coincide with their dominances in both water and sediment of the Yangtze River for Pinnularia, but in sediment for Navicula [41]. The dominance of the benthic diatoms that survive in shallow water and aerophilic conditions shows the peatland's terrestrial environment at $0.5 \mathrm{cal}$. ka BP.

In the Tuul River basin (Figure 6), Cymbella proxima freshwater lentic taxa [42], Gomphonema species characterized by their eurytolerance of flow conditions [40], and Encyonema primarily occur in benthic habitats were identified. The dominant planktonic diatom Cyclotella and benthic diatom Cymbella, Gomphonema, and Amphora species in the core TU08 at 0.9 cal. ka BP coincide with those Bacillariophyte species, particularly Gomphonema olivaceum, Amphora ovalis, and Cocconeis placentula during the high lake levels of soda lakes in the Ulz River and Lake Tari basins of southeastern Siberia [43] and northeastern Mongolia. However, in the Yangtze River, the benthic diatoms were dominated by Bacillariophyceae $(54.88 \%)$, while the planktonic diatoms were dominated by Coscinodiscophyceae $(\sim 43.76 \%)$ [41]. Furthermore, the genera Encyonema and Gomphonema in the core TU08 coincide with those abundances in the core KH09 in the Khuder peatland [16]. The abundant planktonic diatom species Cyclotella ocellata (Figure 6), implying a high water level [44], indicates the prevalence of the humid conditions in the basin at 0.9 cal. ka BP which may have contributed to increased precipitation and inputs of alluvial sediments and mineral fractions (Figure 4B). The genera Cyclotella also coincides with wet conditions intensifying in the Khuder peatland at 1.2-1.0 ka BP with an accretion rate of $0.46 \mathrm{~mm} / \mathrm{yr}$ [16], which may have been induced by the low decomposition of the peat. 


\subsection{Climate-Induced Peatland Development during the Late Holocene}

Climate change has been the significant driver of the peatland evolution in the Terelj River and Tuul River drainage basins in the southern Khentii Mountain Range. The climate change in northeastern Mongolia generally correlates with other records from northern Mongolia and southeastern Siberia, showing the regional extent of paleoclimate changes. Thus, the present study demonstrates the peatland data's suitability to reconstruct the Holocene climatic dynamics in northeastern Mongolia.

The abundant organic matter and biogenic silica in the peatland in the Terelj River basin imply the warm and humid climates (Figure 7). The medium silts (Events 1 and 3 in Figure $3 \mathrm{~A}$ ) and high accretion rate of $0.97 \mathrm{~mm} / \mathrm{yr}$ since $0.5 \mathrm{cal}$. ka BP imply that the humid climate may have contributed to the pulse sedimentations. The records agree with the increase of the vegetation cover density and the development of rich soil cover since $0.65 \mathrm{ka} \mathrm{BP}$ [33] and the peat layer with increased biogenic silica [44]. The climate trend coincides with a comparatively humid condition in the Lake Khagiin Khar basin in the Khentii Mountain Range since 0.4 cal. ka BP [35] (Figure 7) reflected in the lake level and the beginning of the Little Ice Age (LIA), a period of cooling at 0.6-0.1 ka BP with average air temperature across the Northern Hemisphere declined by $0.6^{\circ} \mathrm{C} / \mathrm{yr}$ in comparison to the average air temperature since $0.1 \mathrm{ka}$ BP (e.g., [45,46]). The LIA evidence is also observed in Lake Baikal basin $[47,48]$ in southeastern Siberia, just north of the Khentii Mountain Range, i.e., Lake Baikal dominated by the endemic Cyclotella spp. in the LIA [48] indicates the humidity-induced high lake level at that time.

Moreover, the peatland's environmental condition in the Terelj River basin shifted from arid to humid climates at $0.5 \mathrm{cal}$. ka BP coincides with cooling and wetting conditions, which contributed to the Siberian taiga forest expansion in the landscape around the Shaamar area in the Orkhon River basin during the past 3.0 ka [37] (Figure 7) and the moisture availability in Lake Khuis basin in central Mongolia since 0.5 ka BP varied between sites with no clear regional pattern or relationship to present-day conditions [49]. However, the recent work [50] shows that the regional and local trends in Anthropocene climate changes recorded in the lake basins of Mongolia have differed from each other, with examples of humidifying Lake Darkhad basin, but drying Lakes Khuvsgul and Khargal basins in northern Mongolia, and humidifying Lake Buir basin, but drying Lakes Khukh and Yakhi basins in eastern Mongolia, although all these basins are warming.

The environmental condition of the peatland in the Tuul River basin with moisture availability prior to 0.9 cal. ka BP corresponds to the Medieval Warm Period (MWP), a time of warm climate in the North Atlantic region lasting from 1.1 to $0.7 \mathrm{ka} \mathrm{BP}$ (e.g., [51,52]). The transition from humid to arid climates since $0.9 \mathrm{cal}$. ka BP reflected in the accumulation of the fine silts (e.g., Event 1 in Figure 3A), and the low accretion rate of $0.56 \mathrm{~mm} / \mathrm{yr}$ shows the prevalence of the arid climate in the Tuul River basin (Figure 7). The climate trend in the basin has been extensively a regional pattern. The peak of Aulacoseira alpigena in the Khuder peatland at 1.2-1.0 cal. ka BP replaced with the dominance of benthic genera Tabellaria, Eunotia, and Pinnularia since 1.0 cal. ka BP [16] indicates the decreased precipitation during the past 1000 years. The declined lake level of Lake Gun in the Khyaraa River basin in the northern Khentii Mountain Range, since 1.3 cal. ka BP [15] and 0.5 cal. ka BP [36] implies the dropped rainfall at these periods. Moreover, the forest expansion in the Lake Khuvsgul basin from 3.5 to $1.1 \mathrm{cal}$. ka BP due to an increase of regional moisture [53] implies that the regional humidity was limited since $1.1 \mathrm{cal}$. ka BP.

The present study shows that the climate-induced peatland features in the southern Khentii Mountain Range during the late Holocene is comparable with the Holocene peatland development in the northern Khentii Mountain Range. The peatlands' more precise timing in the Terelj and Tuul Rivers drainage basins is required with multi-disciplinary studies, including geomorphology, sedimentology, and geochronology. In addition to the climate changes, channel modification of the two rivers, human perturbation, and overgrazing in their basins should be taken into account of the peatland evolution because today, the river drainage basins have been major settlement areas for new nomadic families from 
western and southwestern Mongolia and for the recently spoiling touristic spots as their attractive natural landscapes and as advantageous location closer to Ulaanbaatar (Ulaanbaatar has been misspelled as Ulan Bator or Ulan Bataar in publications, Wikipedia, etc. The Ulaanbaatar is the right English translation from Mongolian Улаанбаатар) (Figure 1B), the capital of Mongolia.

\section{Conclusions}

This study documents the late Holocene peatland feature in the Terelj River and Tuul River drainage basins in the Khentii Mountain Range of northeastern Mongolia. In the Terelj River basin, the high organic matter and biogenic silica contents, and abundant diatom assemblages with dominant benthic genera Eunotia, Pinnularia, Navicula, Coloneis, Martyana, Nitzschia, Stauroneis, and Tabellaria in the peatland demonstrate that the prevalence of humid climate since 0.5 cal. ka BP with a high accretion rate of $0.97 \mathrm{~mm} / \mathrm{yr}$. In the Tuul River basin, the large mineral fractions and abundant diatom assemblages with the dominant benthic genera Cymbella, Encyonema, Fragilaria, Gomphonema, Reimera, Punctastriata, and Staurosirella, and planktonic genus Cyclotella in the peatland on the paleo-floodplain indicate the transition from humid to arid climates at 0.9 cal. ka BP with the accretion rate of $0.56 \mathrm{~mm} / \mathrm{yr}$. The present study contributes to further detailed study for the peatland formation and evolution in the Khentii Mountain Range, river valley development (e.g., spatial and temporal changes in the channel, floodplain, and terrace), and human impact in the Terelj River and Tuul River drainage basins.

Author Contributions: Conceptualization, A.O. and G.E.; methodology, A.O. and T.D.; software, M.U.; formal analysis, A.O. and T.D.; writing-original draft preparation, A.O.; writing-review and editing, A.O., T.D., M.U. and G.E.; visualization A.O. and M.U.; APC funding acquisition, A.O. All authors have read and agreed to the published version of the manuscript.

Funding: This research received no external funding. The APC was funded by Fulbright 2021 for A. Orkhonselenge.

Institutional Review Board Statement: Not applicable.

Informed Consent Statement: Not applicable.

Data Availability Statement: Available on request from corresponding author.

Acknowledgments: We thank D. Dorjgotov and O. Batkhishig for fieldwork and K. Kashiwaya and $\mathrm{K}$. Kashima for analyses. We are also grateful to reviewers for valuable suggestions and constructive comments.

Conflicts of Interest: The authors declare no conflict of interest.

\section{References}

1. Mischke, S.; Lee, M.K.; Lee, Y.I. Climate History of Southern Mongolia Since 17 ka: The Ostracod, Gastropod and Charophyte Record from Lake Ulaan. Front. Earth Sci. 2020, 8, 1-15. [CrossRef]

2. Narantsetseg, T.; Krivonogov, S.K.; Oyunchimeg, T.; Uugantsetseg, B.; Burr, G.S.; Tomurhuu, D.; Dolgorsuren, K. Late Glacial to Middle Holocene climate and environmental changes as recorded in Lake Dood sediments, Darhad Basin, northern Mongolia. Quarter. Intern. 2013, 311, 12-24.

3. Orkhonselenge, A.; Komatsu, G.; Uuganzaya, M. Middle to late Holocene sedimentation dynamics and paleoclimatic conditions in the Lake Ulaan basin, southern Mongolia. Géomorph. Rel. Proc. Environ. 2018, 24, 351-363. [CrossRef]

4. Wang, W.; Ma, Y.; Feng, Z.; Narantsetseg, T.; Liu, K.-B.; Zhai, X. A prolonged dry mid-Holocene climate revealed by pollen and diatom records from Lake Ugii Nuur in central Mongolia. Quat. Int. 2011, 229, 74-83. [CrossRef]

5. Dugarjav, C. Effects of Peat and Weathered Coal on the Growth of Pinus sylvestris var. Mongolica Seedlings on Aeolian Sandy Soil; Institute of Botany, Mongolian Academy of Sciences: Ulaanbaatar, Mongolia, 2004; pp. 1-5.

6. Minayeva, T.; Gunin, P.; Sirin, A.; Dugardzhav, C.; Bazha, S. Peatlands in Mongolia: The typical and disappearing landscape. Peatlands Int. 2004, 2, 44-47.

7. Minayeva, T.; Sirin, A.; Dorofeyuk, N.; Smagin, V.; Bayasgalan, D.; Gunin, P.; Dugardjav, C.; Bazha, S.; Tsedendash, G.; Zoyo, D. Mongolia mires: From taiga to desert. In Moore von Sibirien bis Feuerland; Steiner, G.M., Ed.; Stapfia: Biologiezentrum, UK, 2005; Volume 85, pp. 335-352. 
8. Haase, G.; Richter, H.; Barthel, H. Zum Problem landschaftsökologischer Gliederung dargestellt am Beispiel des Changai-gebirges in der Mongolischen Volksrepublik. Wiss. Veruf. Deutsch. Inst. Lunderkd. 1964, 21-22, 489-516.

9. Kulikovskiy, M.; Lange-Bertalot, H.; Witkowski, A.; Dorofeyuk, N. Morphology and taxonomy of selected cymbelloid diatoms from a Mongolian Sphagnum ecosystem with a description of three species new to science. Fottea 2009, 9, 223-232. [CrossRef]

10. Hilbig, W.; Knapp, H.D. Vegetationsmosaik und Florenelemente an der Wald-Steppen-Grenze im Khentey-Gebirge (Mongolei). Flora 1983, 174, 1-89. [CrossRef]

11. Asian Development Bank. Strategic Planning for Peatlands Conservation and Wise Use in Mongolia: Executive Summary of the Assessment Report. Ulaanbaatar, Mongolia. 2017. Available online: https://www.wetlands.org/news/wetlands-internationalleads-strategic-planning-for-peatlands-of-mongolia/ (accessed on 10 November 2017).

12. International Mire Conservation Group. News from Mongolia. Newsl. Issue 2005, 3, 1-17.

13. Joosten, H.; Tapio-Biström, M.L.; Tol, S. Peatlands. In Guidance for Climate Change Mitigation through Conservation, Rehabilitation and Sustainable Use, 2nd ed.; Mitigation of Climate Change in Agriculture (MICCA) Programme; Mitigation of Climate Change in Agriculture Series; Food and Agriculture Organization of the United Nations and Wetlands International: Rome, Italy, 2012; Volume 5, 114p.

14. Hans, J.; Marja, L.; Tapio, B.; Susanna, T. Peatlands-Guidance for Change Mitigation through Conservarion, Rehabilitation and Sustainable Use; Food and Agriculture Organization of the United Nations and Wetlands International: Rome, Italy, 2012; 114p.

15. Dorofeyuk, N.I.; Tarasov, P.E. Vegetation and lake levels of northern Mongolia since 12,500 yr B.P. based on the pollen and diatom records. Strat. Geol. Correl. 1998, 6, 70-83.

16. Fukumoto, Y.; Kashima, K.; Orkhonselenge, A.; Ganzorig, U. Holocene environmental changes in northern Mongolia inferred from diatom and pollen records of peat sediment. Quat. Int. 2012, 254, 83-91. [CrossRef]

17. Asian Development Bank. Mongolia Battles to Save its Peatlands, and a Nomadic Way of Life. Ulaanbaatar, Mongolia. 2018. Available online: https:/ / www.adb.org/results/mongolia-battles-save-its-peatlands-and-nomadic-way-life (accessed on 22 May 2018).

18. Minayeva, T.; Sirin, A.; Dugarjav, C. Highland Peatlands of Mongolia. In The Wetland Book; Finlayson, C., Milton, G., Prentice, R., Davidson, N., Eds.; Springer: Dordrecht, The Netherland, 2016; pp. 1-19.

19. Jigj, S. A Brief Description of Paleoglaciations and Paleoglaciers; Institute of Geography, Mongolian Academy of Sciences: Ulaanbaatar, Mongolia, 1976; 51p.

20. Murzaev, E.M. The Description of Physical Geography of Mongolia, 2nd ed.; State Press: Moscow, Russia, 1952; 472p.

21. Tsegmid, S. Physical Geography of Mongolia; State Press: Ulaanbaatar, Mongolia, 1969; 405p.

22. Orkhonselenge, A.; Davaanyam, S.; Altanbagana, M.; Bolorchuluun, C. Long-Term Changes in Ecosystems in Natural Zones of Mongolia. A Report of Research Project Funded by Science and Technology Foundation (ShUT_A/349_005/2013); Laboratory of Geochemistry and Geomorphology, National University of Mongolia, NUM Publishing: Ulaanbaatar, Mongolia, 2019; 384p.

23. Orkhonselenge, A.; Uuganzaya, M. Glacial Geomorphology of Mt. Asralt Khairkhan and Mt. Baga Khentii Saridag in Khentii Mountain Range, Northeastern Mongolia. Int. J. Geosci. 2018, 9, 308-319. [CrossRef]

24. Academy of Sciences of Mongolia; Academy of Sciences of USSR. National Atlas of the People's Republic of Mongolia; Ulaanbaatar: Moscow, Russia, 1990; 156p.

25. Jambaajamts, C. Climate of Mongolia; State Press: Ulaanbaatar, Mongolia, 1989.

26. Enkhtaivan, D.; Oyungerel, B.; Avirmed, E.; Renchinmyadag, T.; Nyamkhuu, M.; Munkhdulam, O.; Odbaatar, E.; Davaagatan, T.; Bayanjargal, B.; Batnyam, T. Report on research project: Landscape Structure, Change, Planning and Proper Zonation (the Case Study of Eastern Mongolia); Division of Physical Geography, Institute of Geography and Geoecology, Mongolian Academy of Sciences: Ulaanbaatar, Mongolia, 2016; 564p.

27. Dulamsuren, C.; Hauck, M.; Mühlenberg, M. Vegetation at the taiga forest-steppe borderline in the western Khentey Mountains, northern Mongolia. Ann. Bot. Fennici. 2005, 42, 411-426.

28. Mortlock, R.A.; Froelich, P.N. A simple method for the rapid determination of biogenic opal in pelagic marine sediments. Deep. Sea Res. Part A Oceanogr. Res. Pap. 1989, 36, 1415-1426. [CrossRef]

29. Watanabe, T. Picture Book and Ecology of the Freshwater Diatoms; Uchida Rokakuho Publishing Co., Ltd.: Tokyo, Japan, 2005.

30. Bronk-Ramsey, C. Radiocarbon calibration and analysis of stratigraphy: The Oxcal program. Radiocarbon 1995, 37, 425-430. [CrossRef]

31. Bronk-Ramsey, C. Development of radiocarbon program Oxcal. Radiocarbon 2001, 43, 355-363. [CrossRef]

32. Reimer, P.J.; Baillie, M.G.; Bard, E.; Bayliss, A.; Beck, J.W.; Bertrand, C.J.; Blackwell, P.G.; Buck, C.E.; Burr, G.S.; Cutler, K.B.; et al. Intcal04 Terrestrial Radiocarbon Age Calibration, 0-26 Cal Kyr BP. Radiocarbon 2004, 46, 1029-1058. [CrossRef]

33. Shchetnikov, A.; Bezrukova, E.V.; Alexander, S. Lakes of the Jom-Bolok Volcanoes Valley in the East Sayan Mts., Baikal region. J. Geogr. Sci. 2019, 29, 1823-1840. [CrossRef]

34. Orkhonselenge, A.; Krivonogov, S.; Mino, K.; Kashiwaya, K.; Safonova, I.; Yamamoto, M.; Kashima, K.; Nakamura, T.; Kim, J. Holocene sedimentary records from Lake Borsog, eastern shore of Lake Khuvsgul, Mongolia, and their paleoenvironmental implications. Quat. Int. 2013, 290, 95-109. [CrossRef]

35. Oh, J.-S.; Seong, Y.B.; Hong, S.; Yu, B.Y. Paleo-shoreline changes in moraine dammed lake Khagiin Khar, Khentey Mountains, Central Mongolia. J. Mt. Sci. 2019, 16, 1215-1230. [CrossRef]

36. Zhang, C.; Zhang, W.; Feng, Z.; Mischke, S.; Gao, X.; Gao, D.; Sun, F. Holocene hydrological and climatic change on the northern Mongolian Plateau based on multi-proxy records from Lake Gun Nuur. Palaeogeogr. Palaeoclim. Palaeoecol. 2012, 75-86. [CrossRef] 
37. Ma, Y.; Liu, K.-B.; Feng, Z.; Meng, H.; Sang, Y.; Wang, W.; Zhang, H. Vegetation changes and associated climate variations during the past $\sim 38,000$ years reconstructed from the Shaamar eolian-paleosol section, northern Mongolia. Quat. Int. 2013, 311, 25-35. [CrossRef]

38. Pienitz, R.; Smol, J.P. Diatom assemblages and their relationship to environmental variables in lakes from the boreal forest-tundra ecotone near Yellowknife, Northwest Territories, Canada. Hydrobiologia 1993, 269, 391-404. [CrossRef]

39. Blinn, D.W.; Poff, L. Colorado River Basin. In Rivers of North America; Benke, A.C., Cushing, C.E., Eds.; Academic Press: San Diego, CA, USA, 2005; pp. 482-538.

40. Kociolek, J.P.; Spaulding, S.A. Eunotioid and Asymmetrical Naviculoid Diatoms. Freshw. Algae N. Am. 2003, 655-668.

41. Wang, J.; Liu, Q.; Zhao, X.; Borthwick, A.G.L.; Liu, Y.; Chen, Q.; Ni, J. Molecular biogeography of planktonic and benthic diatoms in the Yangtze River. Microbiome 2019, 7, 1-15. [CrossRef]

42. Patrick, R.M.; Reimer, C.W. The diatoms of the United States; Monograph 13; Academy of Natural Sciences of Philadelphia: Philadelphia, PA, USA, 1975; Volume 2, Part 1; 213p.

43. Afonina, E.Y.; Tashlykova, N.A. Fluctuations in plankton community structure of endorheic soda lakes of southeastern Transbaikalia (Russia). Hydrobiologia 2020, 847, 1383-1398. [CrossRef]

44. Kokfelt, U.; Struyf, E.; Randsalu, L. Diatoms in peat-Dominant producers in a changing environment? Soil Biol. Biochem. 2009, 41, 1764-1766. [CrossRef]

45. Grove, J.M. Little Ice Ages: Ancient and Modern; Routledge: London, UK, 2004.

46. Matthews, J.A.; Briffa, K.R. The 'little ice age': Re-evaluation of an evolving concept. Geogr. Ann. Ser. A Phys. Geogr. 2005, 87, 17-36. [CrossRef]

47. Demske, D.; Heumann, G.; Granoszewski, W.; Nita, M.; Mamakowa, K.; Tarasov, P.E.; Oberhänsli, H. Late glacial and Holocene vegetation and regional climate variability evidenced in high-resolution pollen records from Lake Baikal. Glob. Planet. Chang. 2005, 46, 255-279. [CrossRef]

48. Edlund, M.B.; Stoermer, E.F.; Pilskaln, C.H. Siliceousmicrofossil succession in the recent history of two basins in Lake Baikal, Siberia. J. Paleolim. 1995, 14, 165-184. [CrossRef]

49. Tian, F.; Herzschuh, U.; Dallmeyer, A.; Xu, Q.; Mischke, S.; Biskaborn, B.K. Environmental variability in the monsoon-westerlies transition zone during the last 1200 years: Lake sediment analyses from central Mongolia and supra-regional synthesis. Quarter. Sci. Rev. 2013, 73, 31-47. [CrossRef]

50. Orkhonselenge, A.; Komatsu, G. Lacustrine Geomorphology of Mongolia; Springer Nature: London, UK, 2021; in press.

51. Mann, M.E.; Zhang, Z.; Rutherford, S.; Bradley, R.S.; Hughes, M.K.; Shindell, D.; Ammann, C.; Faluvegi, G.; Ni, F. Global Signatures and Dynamical Origins of the Little Ice Age and Medieval Climate Anomaly. Science 2009, 326, 1256-1260. [CrossRef] [PubMed]

52. Wanner, H.; Beer, J.; Bütikofer, J.; Crowley, T.J.; Cubasch, U.; Flückiger, J.; Goosse, H.; Grosjean, M.; Joos, F.; Kaplan, J.O.; et al. Mid to Late Holocene climate change: An overview. Quat. Sci. Rev. 2008, 27, 1791-1828. [CrossRef]

53. Prokopenko, A.A.; Khursevich, G.K.; Bezrukova, E.V.; Kuzmin, M.I.; Boes, X.; Williams, D.F.; Fedenya, S.A.; Kulagina, N.V.; Letunova, P.P.; Abzaeva, A.A. Paleoenvironmental proxy records from Lake Hovsgol, Mongolia, and a synthesis of Holocene climate change in the Lake Baikal watershed. Quat. Res. 2007, 68, 2-17. [CrossRef] 